\title{
U-Mo Mechanical Properties Degradation with Irradiation
}

\author{
Jason L Schulthess
}

November 2018

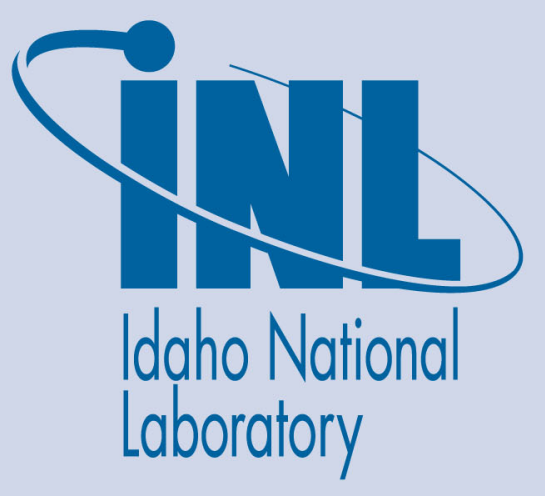

The INL is a U.S. Department of Energy National Laboratory operated by Battelle Energy Alliance 


\title{
U-Mo Mechanical Properties Degradation with Irradiation
}

\author{
Jason L Schulthess
}

November 2018

Idaho National Laboratory Idaho Falls, Idaho 83415

http://www.inl.gov

Prepared for the U.S. Department of Energy

National Nuclear Security Administration Under DOE Idaho Operations Office

Contract DE-AC07-05ID14517 


\title{
Degradation of Mechanical Properties of U-Mo Alloy from the Un-irradiated to Irradiated State
}

\author{
Jason Schulthess
}

Thesis Committee: Dr. Richard Christensen, Dr. Jim Cole, Dr. Indrajit Charit

November 2018

INL/MIS-18-51872

Idaho National Laboratory 


\section{Outline}

- Background

- Fuel Qualification Requirements

- Fuel Form

- Motivation

- Part 1 - Un-irradiated Properties

- Existing Data

- Source Material

- Experimental Results

- Part 2 - Irradiated Properties

- Existing Data

- Source Material

- Analysis Methodology

- Experimental Results

- Porosity Discussion

- Summary 


\section{Materials Management and Minimization (M3)}

- Mission:

- Eliminate the use of high enriched uranium (HEU) for use in research and test reactors by developing and qualifying a low enriched uranium (LEU) fuel to replace the current HEU fuel.

- Six domestic High Performance Research Reactors (HPRRs) require a new high density LEU fuel form.

- Massachusetts Institute of Technology (MITR),

- University of Missouri (MURR),

- National Institute of Standards and Technology (NIST),

- High Flux Isotope Reactor (HFIR) at Oak Ridge National Laboratory and

- Advanced Test Reactor (ATR) at Idaho National Laboratory (INL) and its associated critical assembly (ATRC).

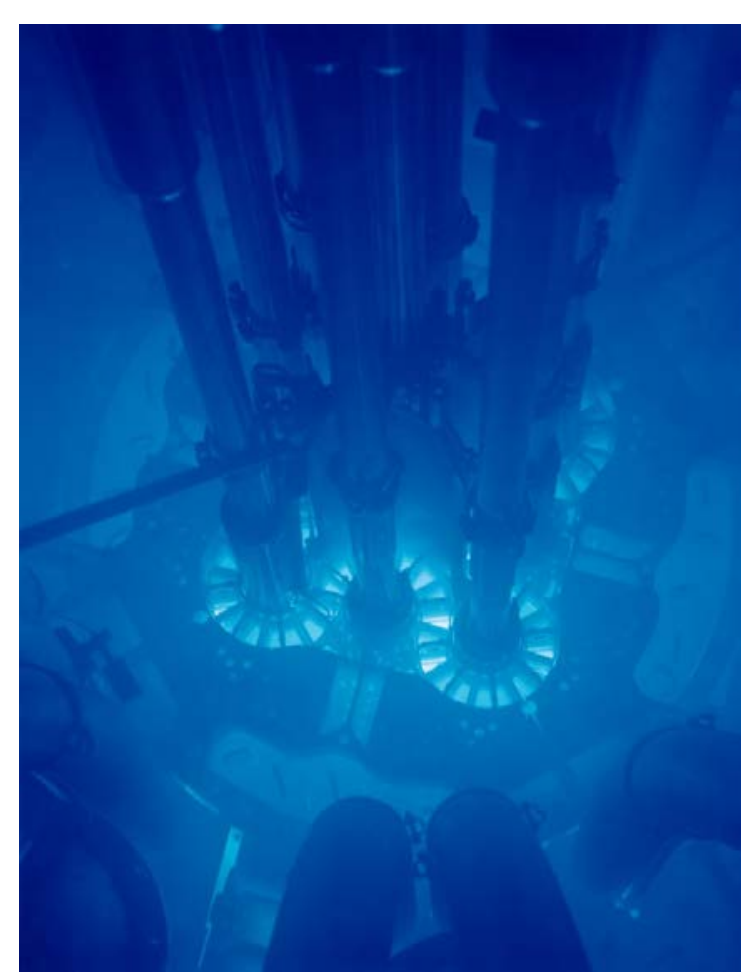

ATR Core (INL) 


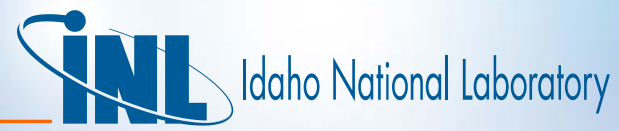

\section{Fuel Requirements}

Focus of Fuel Development irradiation testing

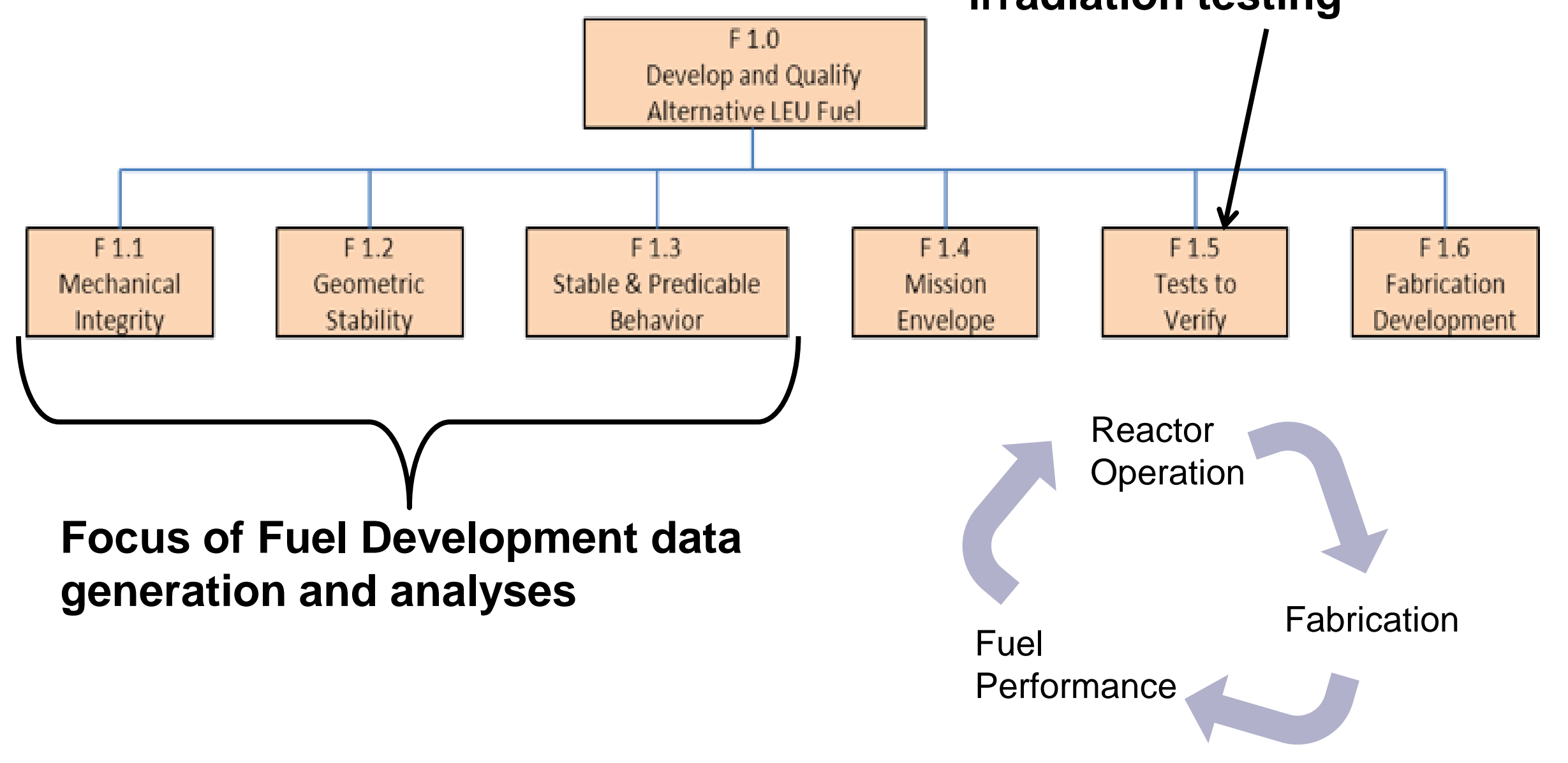




\section{Summary of Fuel Performance Requirements}

\section{Mechanical Integrity}

- Ensure no delamination during normal operation and anticipated transients

- Mechanical response of the fuel meat, cladding, and interlayers is established
Geometric Stability

- Plate movement

caused by pressure

differential does not

compromise ability to

cool the fuel

- Geometry is

maintained during

normal operation and

anticipated transients

- Irradiation-induced

degradation of

properties does not

lead to conditions

that result in loss of

coolability
Stable and Predictable Behavior

-

- Euer jelformance shati

be known and

predictable

- Fuel swelling is within

a stable regime

- U-Mo corrosion

behavior after breach

is known

- Irradiation behavior on scale up is predictable 


\section{Fuel Sandwich}

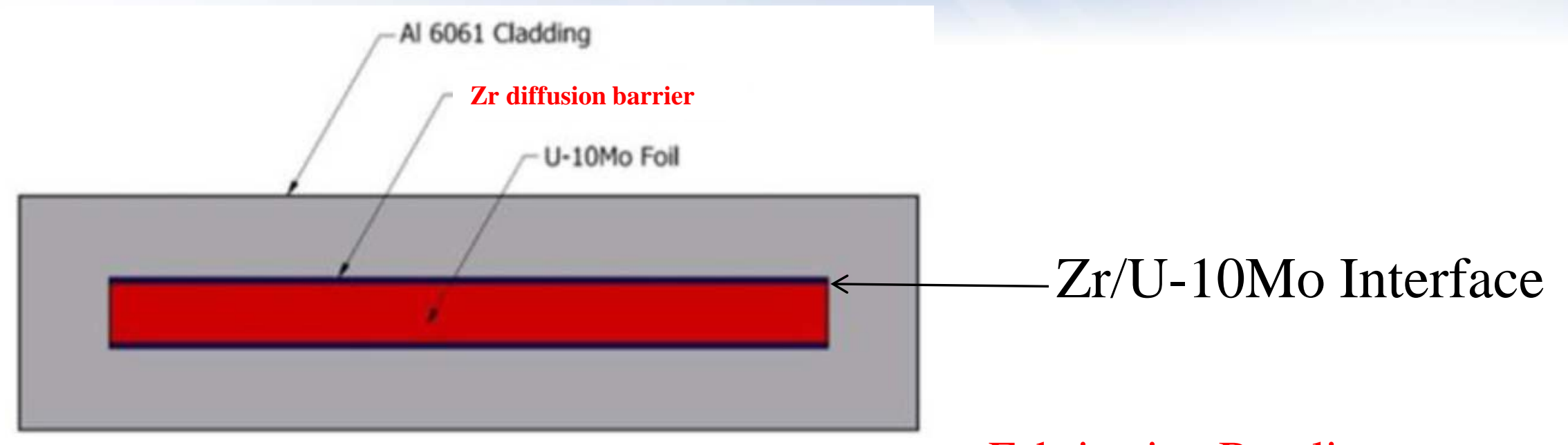

Fabrication Baseline

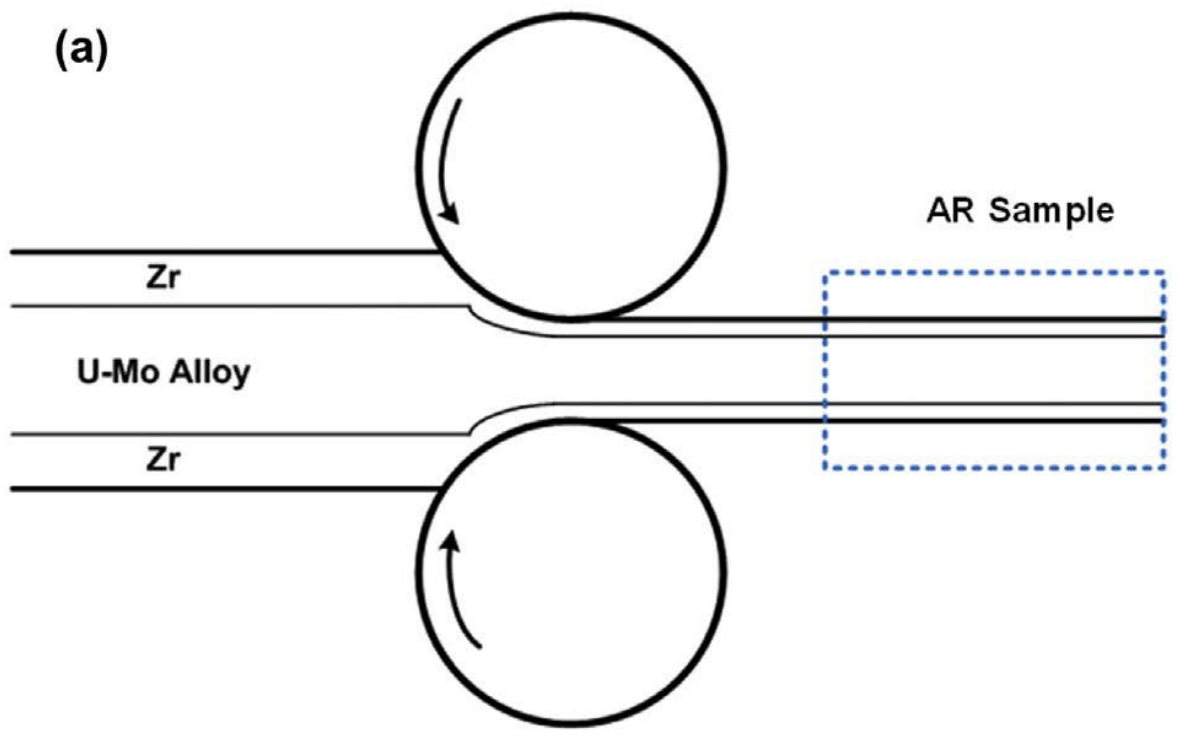

- U-10Mo fabricated by wrought thermomechanical processing (hot and cold rolling) 


\section{Motivation:}

- What are the U-Mo mechanical properties, and can the degradation of mechanical properties from irradiation be correlated with porosity?

- Part 1: What are the un-irradiated mechanical properties, and what is the influence of temperature and variations of wrought processing on the mechanical properties

- Part 2: What are the irradiated mechanical properties and can the degradation be correlated with increasing porosity from irradiation 


\section{PART 1 - Un-irradiated Properties}




\section{Existing Data:}

\section{Note: nothing that was cold rolled!}

\begin{tabular}{|c|c|c|c|c|c|c|c|c|c|}
\hline 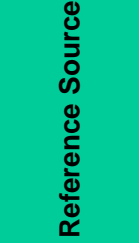 & 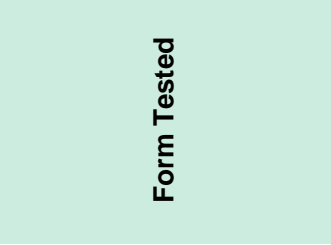 & 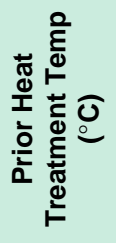 & 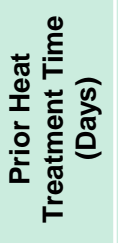 & 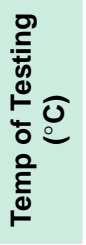 & 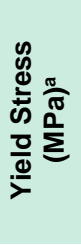 & 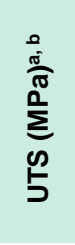 & 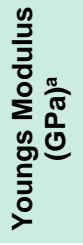 & 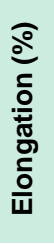 & 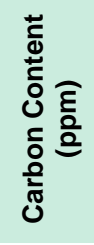 \\
\hline Waldron & As-cast & 900 & 7 & 20 & NA & 617.8 & 86.87 & 0.1 & $\sim 700$ \\
\hline Waldron & As-cast & 450 & 14 & 20 & NA & 293.7 & 119.3 & 0.8 & $\sim 700$ \\
\hline Ozaltun & $\begin{array}{c}\text { Hot Rolled with } 90 \% \text { reduction at } \\
650^{\circ} \mathrm{C} \text {; annealed at either } 650^{\circ} \mathrm{C} \\
\text { or } 675^{\circ} \mathrm{C} \text { for durations of } 0.5,1 \text { or } \\
22 \mathrm{~h}\end{array}$ & NA & NA & 21 & 780 & 790 & 65 & NA & $-54-410$ \\
\hline Ozaltun & Cast and machined & NA & NA & 94 & 760 & 760 & NA & NA & NA \\
\hline Waldron & As-cast & 900 & 7 & 200 & NA & 510.2 & 73.77 & 0.5 & $\sim 700$ \\
\hline Waldron & As-cast & 450 & 14 & 200 & NA & 303.4 & 91.7 & Nil & -700 \\
\hline Kalashnikov & $\begin{array}{l}\text { Hot Rolled between } 900-1200^{\circ} \mathrm{C} \\
\text { followed by water quenching from } \\
900^{\circ} \mathrm{C} \text {. Held at } 900^{\circ} \mathrm{C} \text { for } 7 \text { days }\end{array}$ & NA & NA & 200 & NA & 578.6 & NA & 0.5 & NA \\
\hline Ozaltun & Cast and machined & NA & NA & 205 & 655 & 655 & NA & NA & NA \\
\hline Waldron & As-cast & 450 & 14 & 300 & NA & 183.4 & 103.4 & 0.5 & $\sim 700$ \\
\hline Ozaltun & Cast and machined & NA & NA & 316 & 527 & 536 & NA & NA & NA \\
\hline Waldron & As-cast & 900 & 7 & 400 & NA & 358.5 & 51.71 & 1 & $\sim 700$ \\
\hline Waldron & As-cast & 450 & 14 & 400 & NA & 256.5 & 108.9 & 0.5 & -700 \\
\hline Waldron & As-cast & 575 & 28 & 400 & NA & 148.9 & 84.12 & 2 & $\sim 700$ \\
\hline Kalashnikov & $\begin{array}{l}\text { Hot Rolled between } 900-1200^{\circ} \mathrm{C} \\
\text { followed by water quenching from } \\
900^{\circ} \mathrm{C} \text {. Held at } 900^{\circ} \mathrm{C} \text { for } 7 \text { days }\end{array}$ & NA & NA & 400 & NA & 397.2 & NA & 1 & NA \\
\hline Ozaltun & Cast and machined & NA & NA & 427 & 474 & 511 & NA & NA & NA \\
\hline Ozaltun & Cast and machined & NA & NA & 538 & 427 & 440 & NA & NA & NA \\
\hline Waldron & As-cast & 900 & 7 & 600 & NA & 179.3 & 33.09 & 0 & -700 \\
\hline Waldron & As-cast & 575 & 28 & 600 & NA & 124.1 & 59.29 & 0.5 & $\sim 700$ \\
\hline Kalashnikov & $\begin{array}{l}\text { Hot Rolled between } 900-1200^{\circ} \mathrm{C} \\
\text { followed by water quenching from } \\
900^{\circ} \mathrm{C} \text {. Held at } 900^{\circ} \mathrm{C} \text { for } 7 \text { days }\end{array}$ & NA & NA & 600 & NA & 194.2 & NA & NA & NA \\
\hline Waldron & As-cast & 900 & 7 & 800 & NA & 55.16 & 41.37 & 3 & $\sim 700$ \\
\hline Waldron & As-cast & 575 & 28 & 800 & NA & 86.9 & 59.29 & 11 & $\sim 700$ \\
\hline Kalashnikov & $\begin{array}{l}\text { Hot Rolled between } 900-1200^{\circ} \mathrm{C} \\
\text { followed by water quenching from } \\
900^{\circ} \mathrm{C} \text {. Held at } 900^{\circ} \mathrm{C} \text { for } 7 \text { days }\end{array}$ & NA & NA & 800 & NA & 62.8 & NA & 30 & NA \\
\hline
\end{tabular}

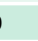




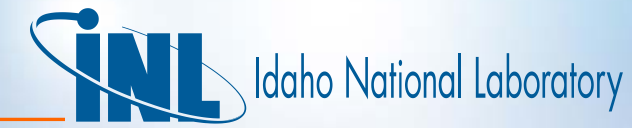

\section{Un-irradiated material used in this study}

- DU-10Mo cast at Y-12 (carbon 710 ppm)

- Homogenized at $1000^{\circ} \mathrm{C}$ for 2 hours under vacuum of $5 \times 10^{-6}$ Torr

- Hot rolled at $650^{\circ} \mathrm{C}$

- 4 thermomechanical conditions

- Foil 551-2, hot rolled from $-3.66 \mathrm{~mm}$ to $\sim 0.762 \mathrm{~mm}$ (79\% reduction), followed by additional $50 \%$ cold-rolling reduction to $\sim 0.38 \mathrm{~mm} ; 551-2$ $50 \% \mathrm{CW}$

- Foil 551-3, hot rolled from $-3.66 \mathrm{~mm}$ to $\sim 0.762 \mathrm{~mm}$ (79\% reduction), followed by additional $50 \%$ cold-rolling reduction to $\sim 0.38 \mathrm{~mm}$, followed by stress-relief annealing at $650^{\circ} \mathrm{C}$ for one hour; 551-3 50\% CW+A

- Foil 551-4, hot rolled from $-3.66 \mathrm{~mm}$ to $\sim 0.483 \mathrm{~mm}$ (87\% reduction), followed by additional $20 \%$ cold-rolling reduction to $\sim 0.38 \mathrm{~mm} ; 551-420 \%$ CW

- Foil 551-5, hot rolled from $-3.66 \mathrm{~mm}$ to $\sim 0.540 \mathrm{~mm}$ (85\% reduction) no further processing, i.e. hot-rolled only; 551-5 HR Only 


\section{Metallography of the as-rolled material}

\section{1-2-2-L11 50\%CW}

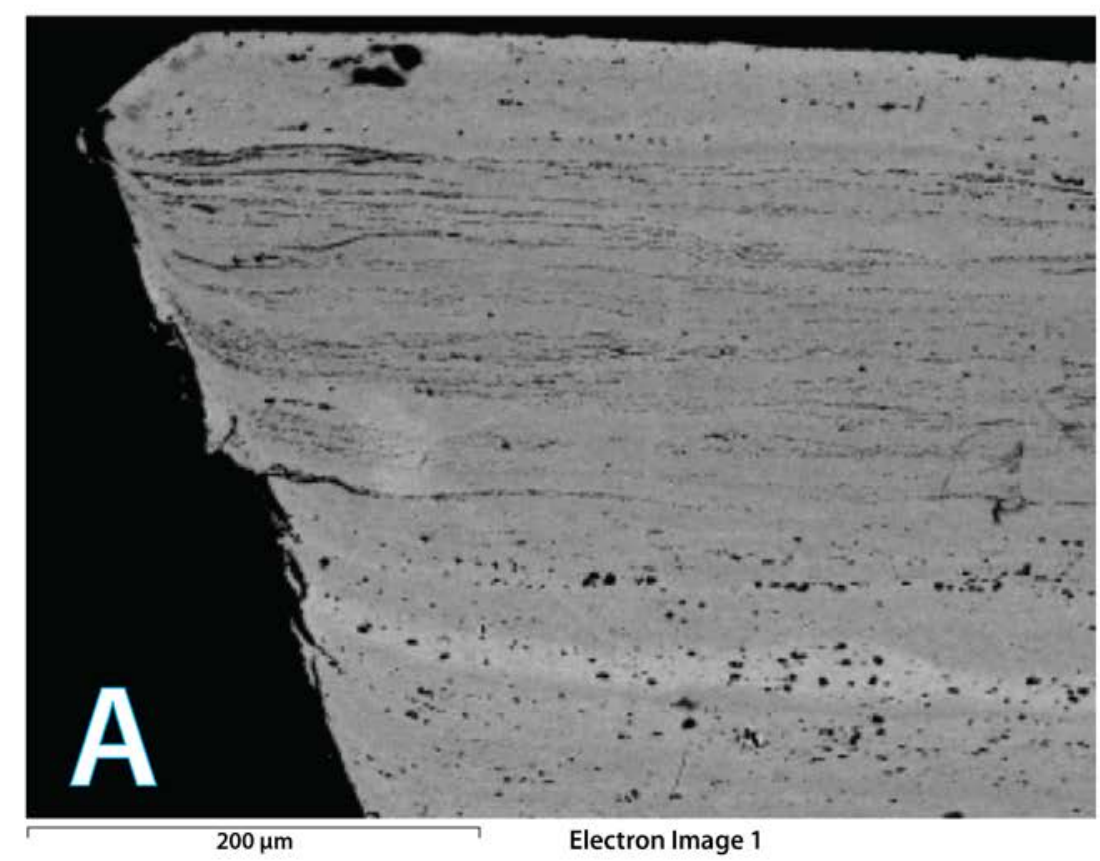

Mo banding varies between $8.35 \mathrm{wt} \%$ and $10.45 \mathrm{wt} \%$

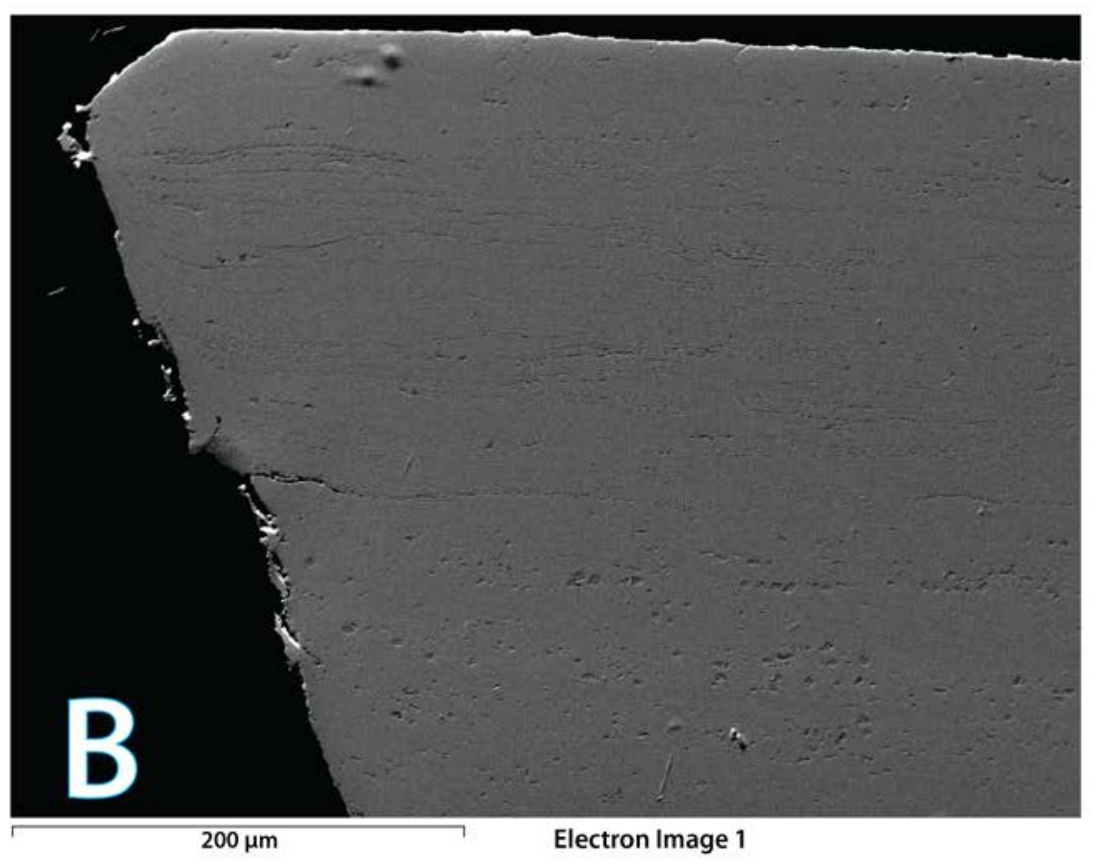

Grain sizes for the longitudinal and transvers cross-sections ranged from 2 to $22 \mu \mathrm{m}$ with the greatest concentration between 15 and 18 $\mu \mathrm{m}$ for the longitudinal direction and between 7 and $8 \mu \mathrm{m}$ for the transverse direction. 


\section{Metallography of the as-rolled material}

\section{1-3-L30 50\%CW+A}

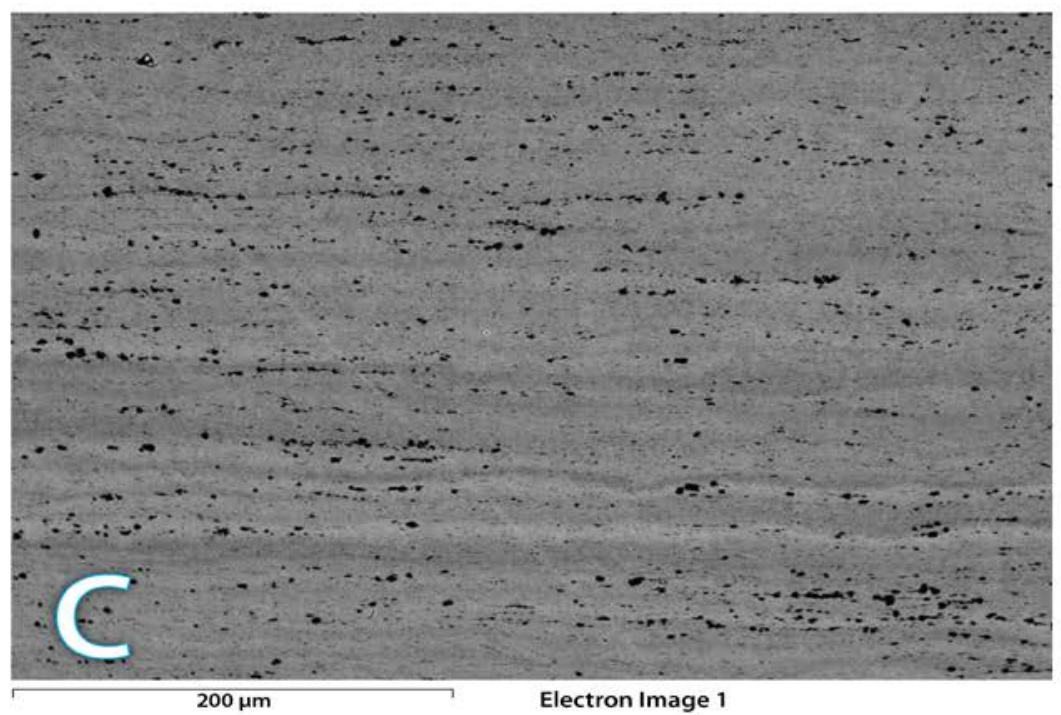

$200 \mu \mathrm{m}$

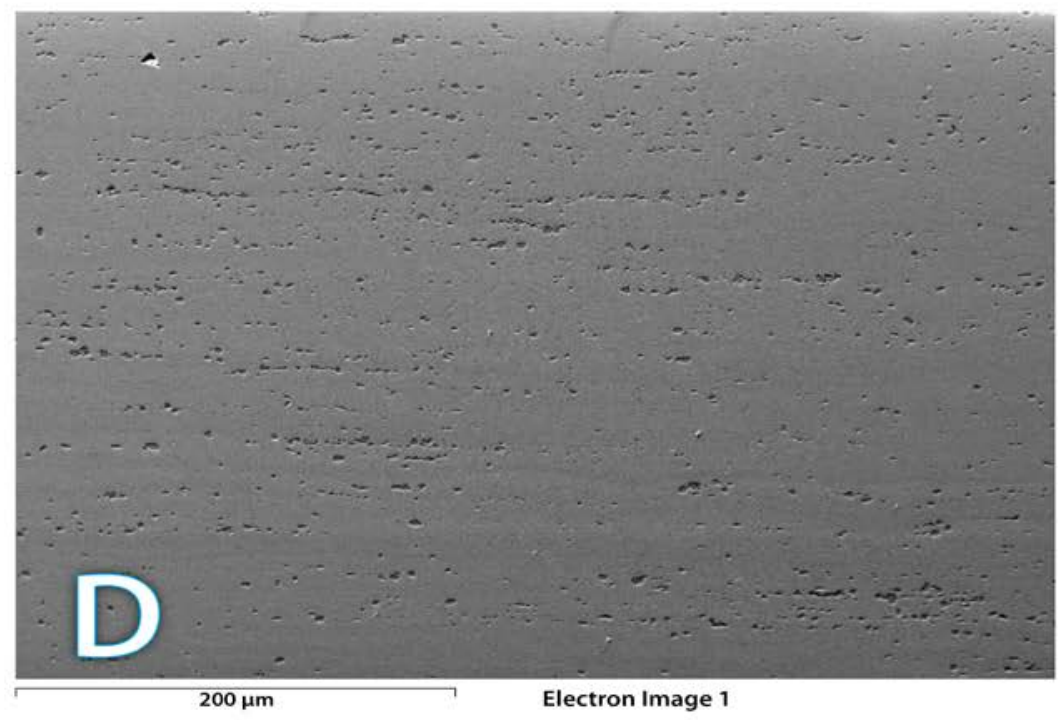

\section{Mo banding ranges from $8.96 \mathrm{wt} \%$ to $10.81 \mathrm{wt} \%$.}

Grains in the range between 2 to $12 \mu \mathrm{m}$ with the greatest concentration of grain sizes between 5 to $9 \mu \mathrm{m}$ for both the longitudinal and transvers directions). The grains in this microstructure do not appear to show significant grain elongation. The grains in this microstructure appear more equiaxed. 


\section{Metallography of the as-rolled material}

\section{1-4-L14 20\%CW}
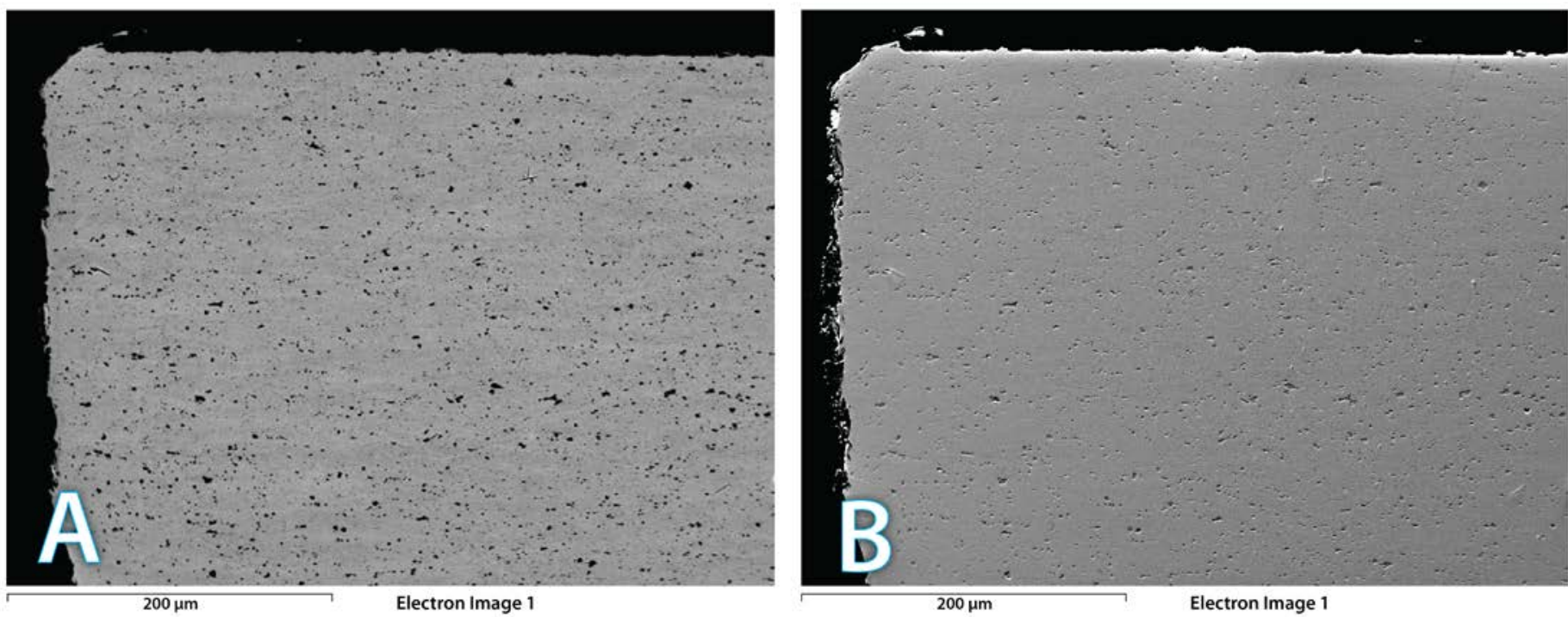

Mo banding ranges from 9.81 wt\% to $10.45 \mathrm{wt} \%$
Grains between 2 to $25 \mu \mathrm{m}$ with the greatest concentration of grains between 7 to $17 \mu \mathrm{m}$ for both the longitudinal and transvers directions). The grains in this microstructure do appear to show elongation. 


\section{Metallography of the as-rolled material}

\section{1-5-L13 HR Only}

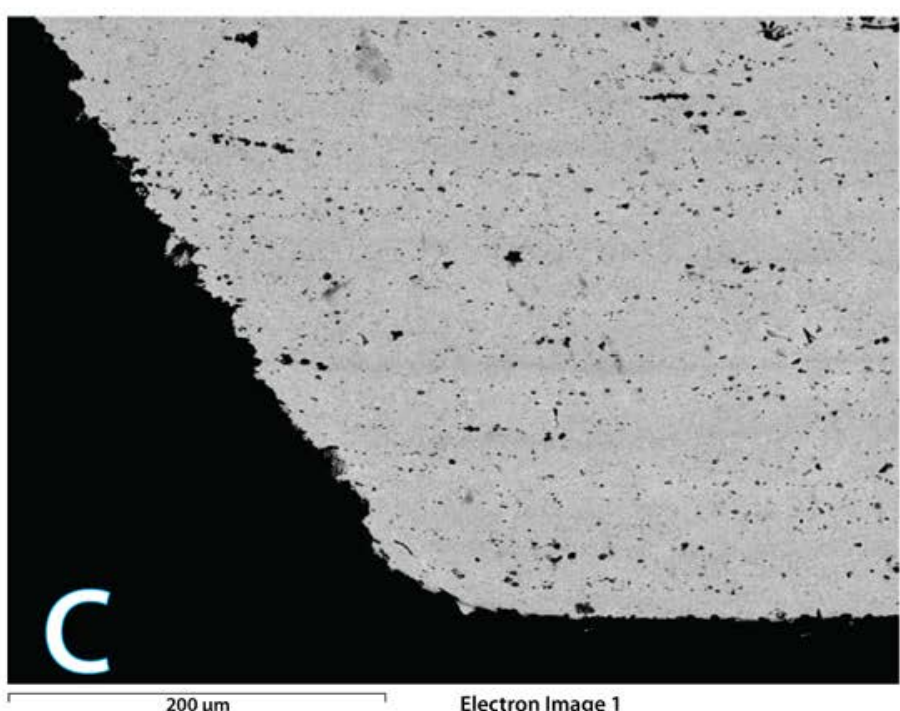

$200 \mu \mathrm{m}$

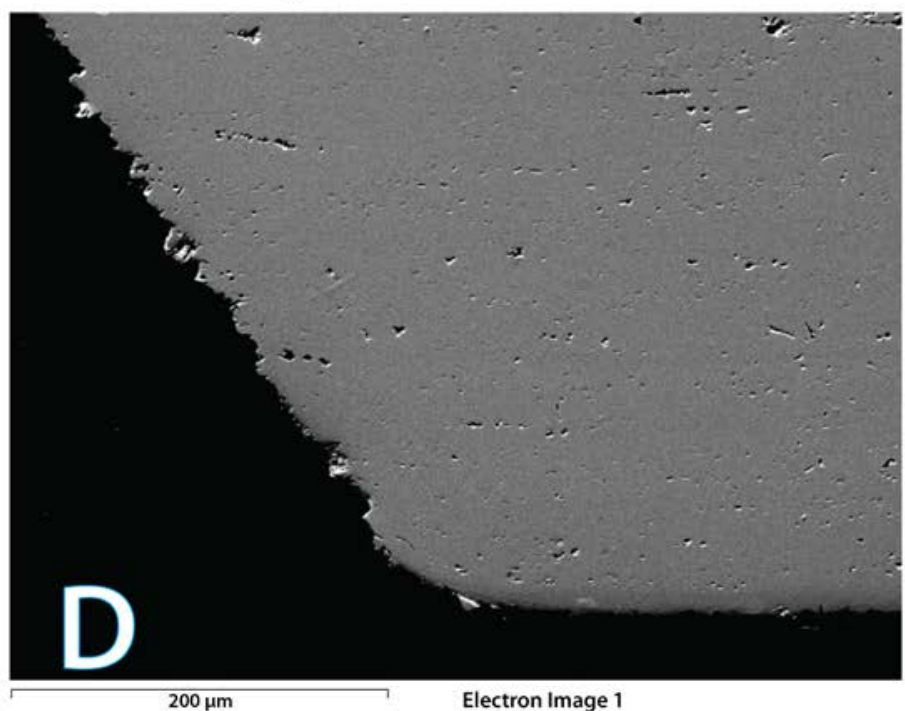

Grains between 2 and $22 \mu \mathrm{m}$ with the greatest concentration in the longitudinal sample being $20 \mu \mathrm{m}$ and the greatest concentration in the transvers sample being between 7 and $10 \mu \mathrm{m}$. The grains in this microstructure appear to show some grain elongation. 


\section{Mechanical Properties Results}
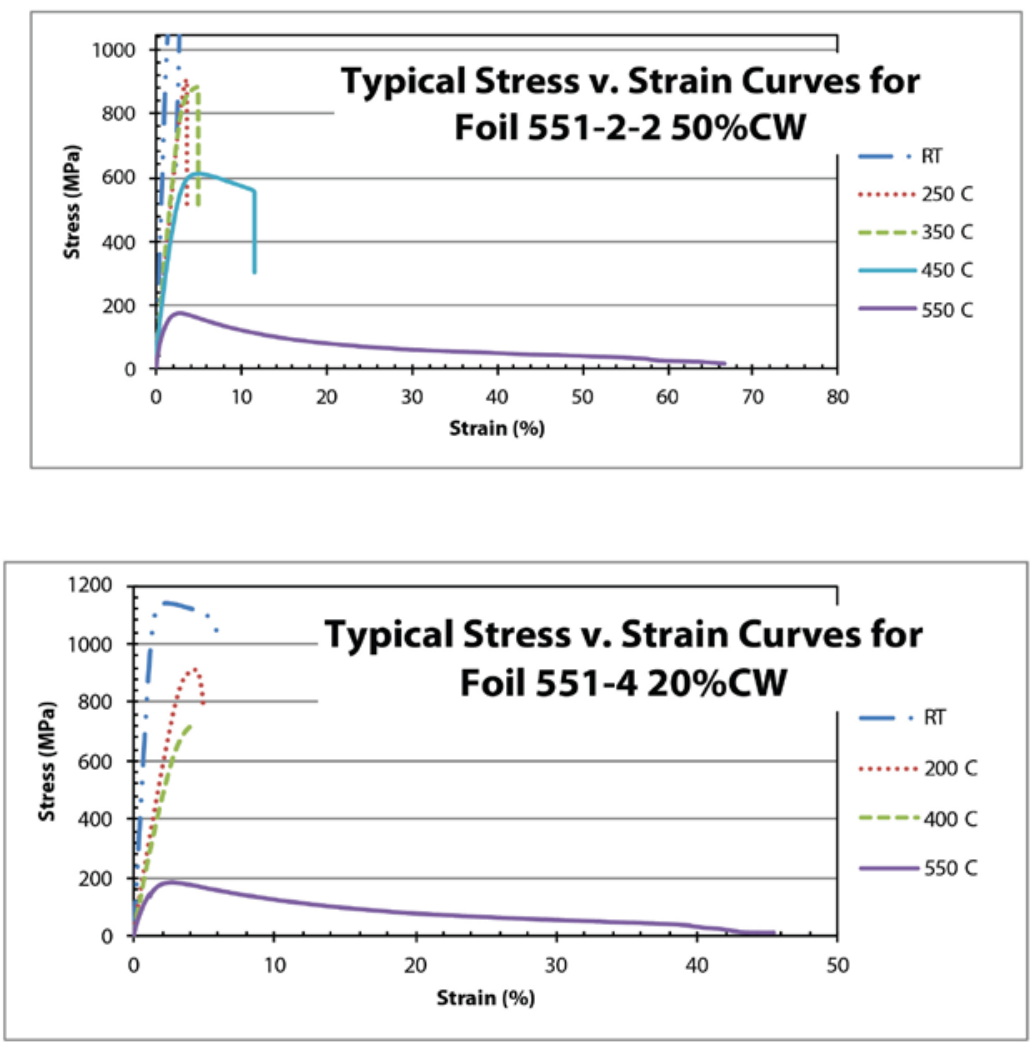
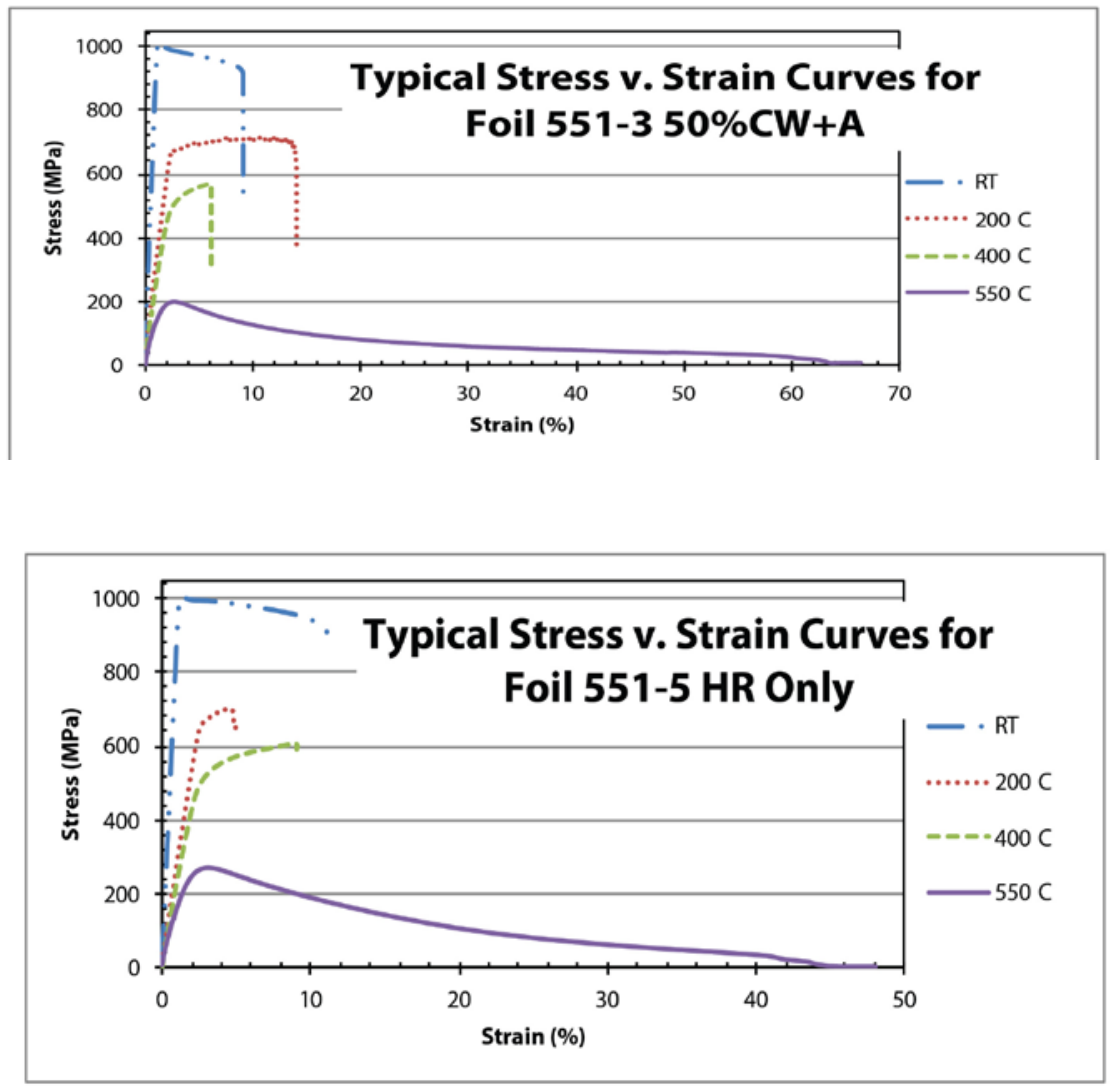


\section{Yield Stress}

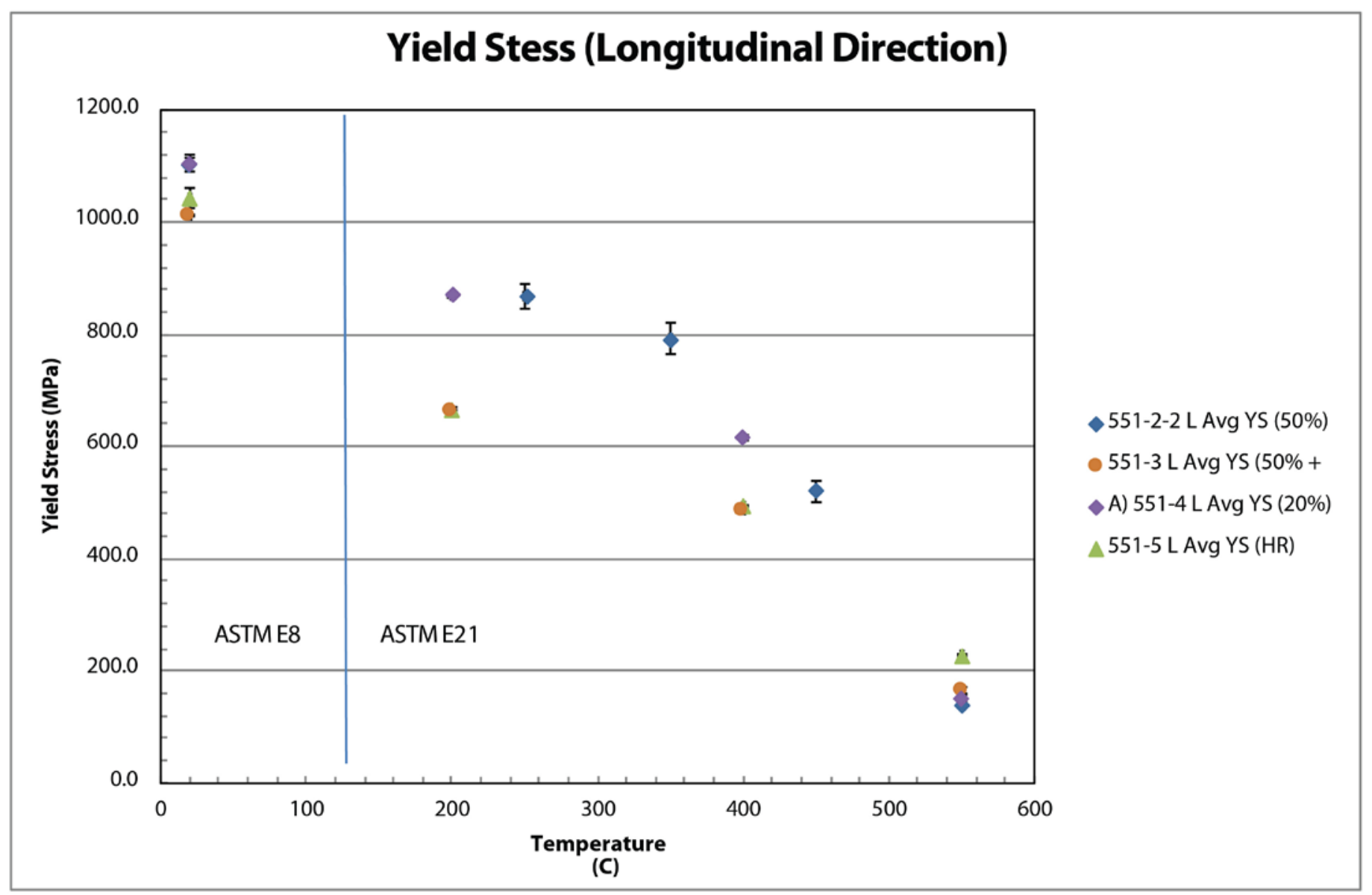

Results for Ultimate stress are similar. 


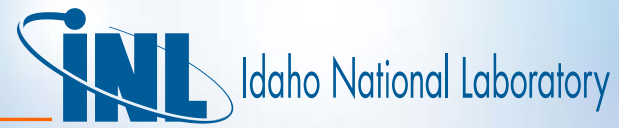

\section{Elongation}

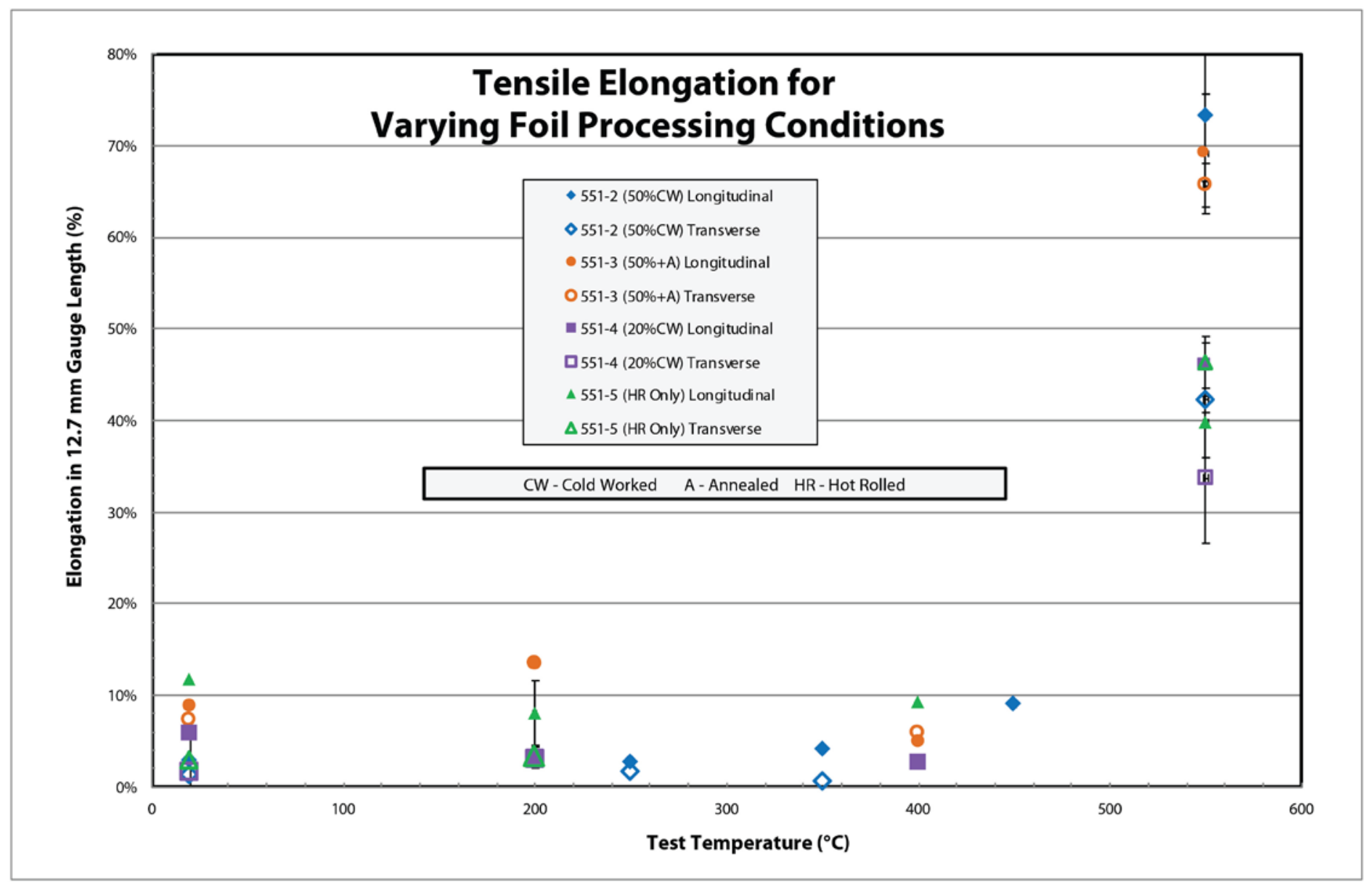




\section{Elastic Modulus}

- Testing per ASTM E8 and ASTM E21... NOT ASTM E111

- Nevertheless, the slope of the elastic portion of the stress strain curve is at each temperature:

$-20^{\circ} \mathrm{C}$ - $\sim 884 \mathrm{MPa} / \%$

$-200-250^{\circ} \mathrm{C}-\sim 417 \mathrm{MPa} / \% \longleftarrow$ Unclear what caused

$-350^{\circ} \mathrm{C}-\sim 422 \mathrm{MPa} / \%$ this unexpected result

$-400-450^{\circ} \mathrm{C}-\sim 320 \mathrm{MPa} / \%$

- $550^{\circ} \mathrm{C}$ - $\sim 199 \mathrm{MPa} / \%$

- $1000 \mathrm{MPa} / \%=100 \mathrm{GPa}(884 \mathrm{MPa} / \%=88.4 \mathrm{GPa})$ 


\section{Fractography-1}
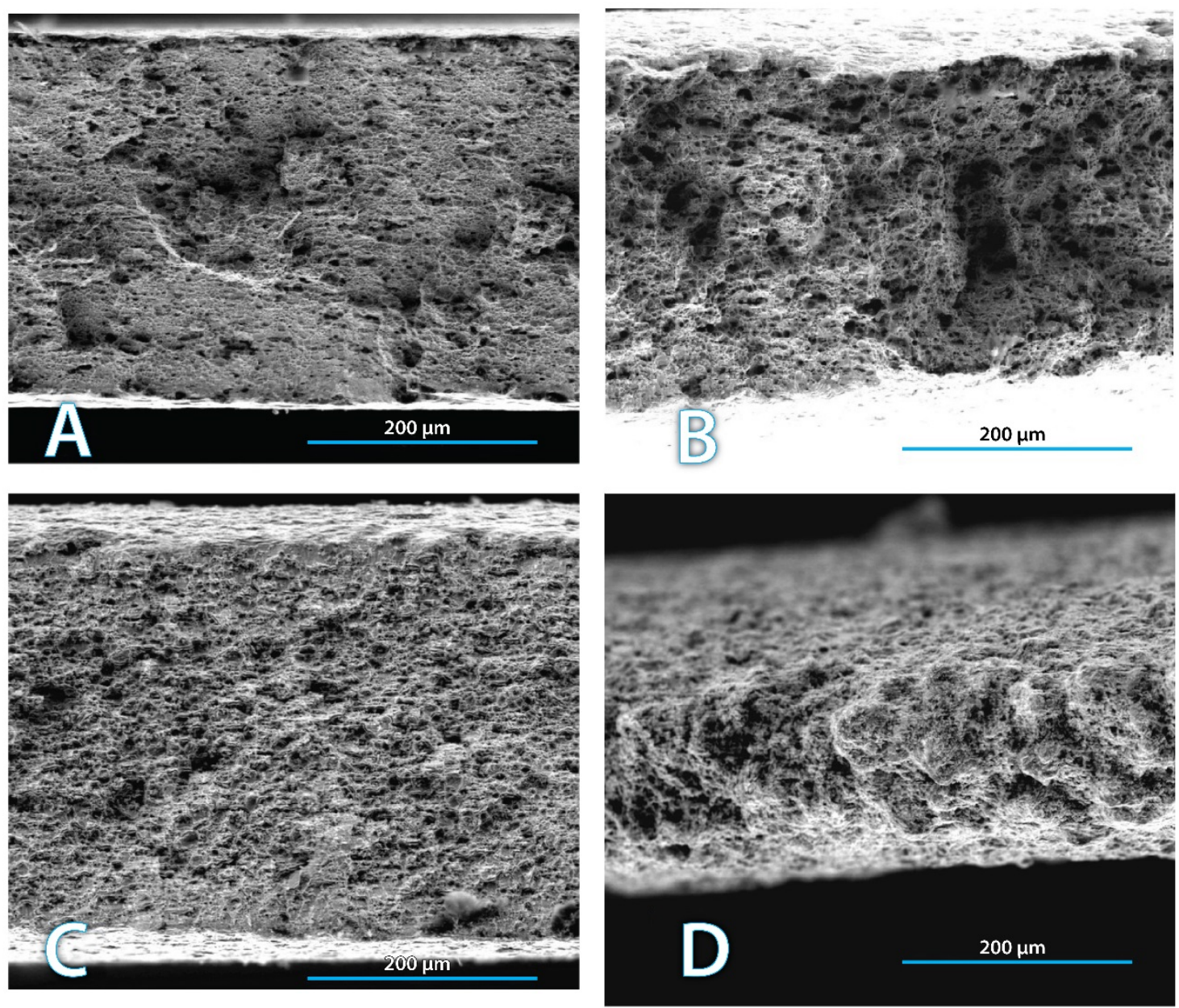

Fractography images set one. One foil condition (551-3 50\%CW+A) at all test temperatures.

A) 551-3-L1, tested at room temperature, B) 551-3-L4, tested at $200^{\circ} \mathrm{C}$,

C) $551-3-\mathrm{L} 7$, tested at $400^{\circ} \mathrm{C}$, D) $551-3 \mathrm{~L} 10$, tested at $550{ }^{\circ} \mathrm{C}$. 


\section{Fractography-2}
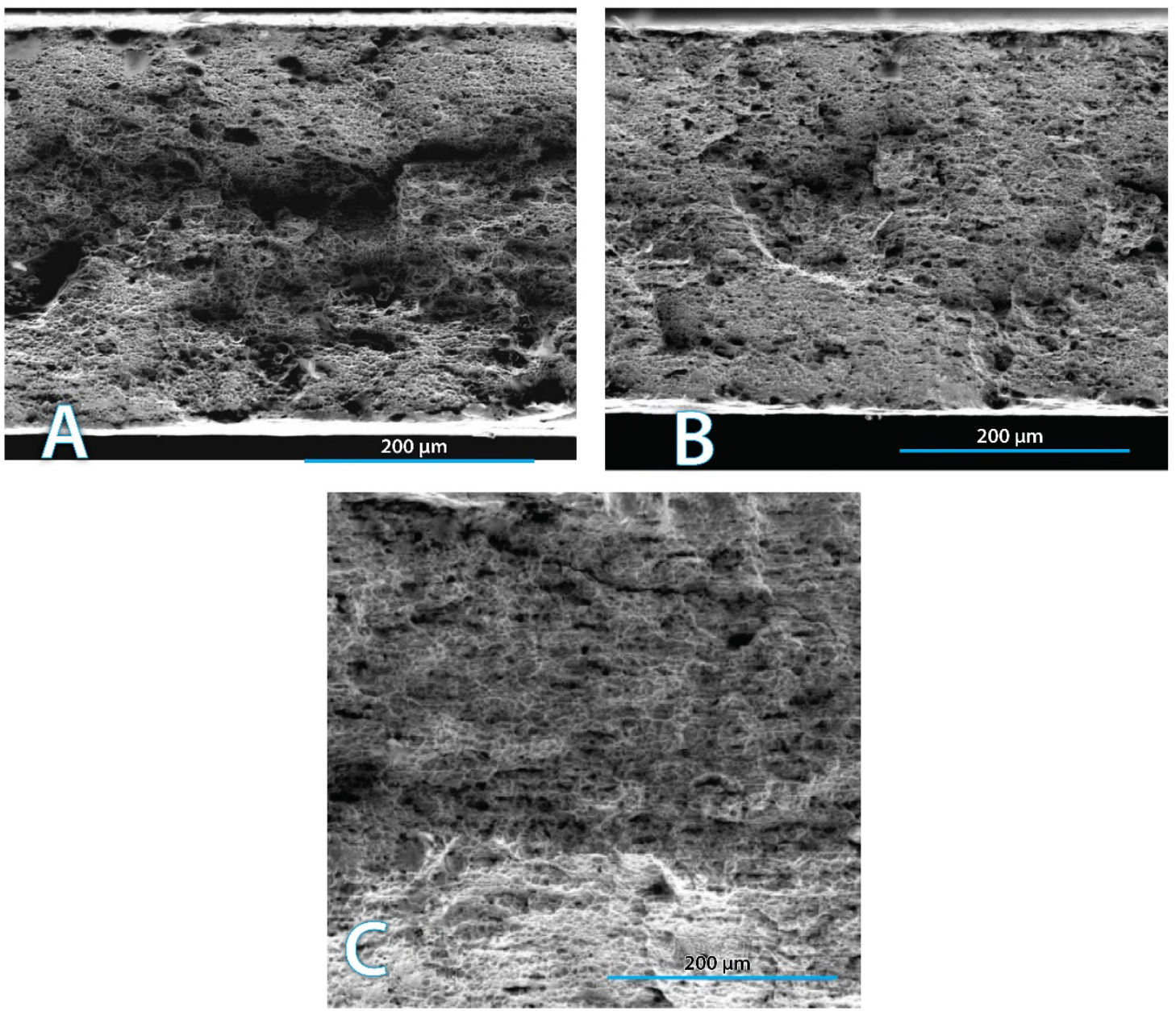

Fractography images set two. Different foil conditions, all tested at room temperature.

A) 551-2-2-L16-RT (50\%CW), B) 551-3-L1-RT (50\%CW+A), C) 551-5-T13-RT.(HR only). 


\section{Fractography-3}
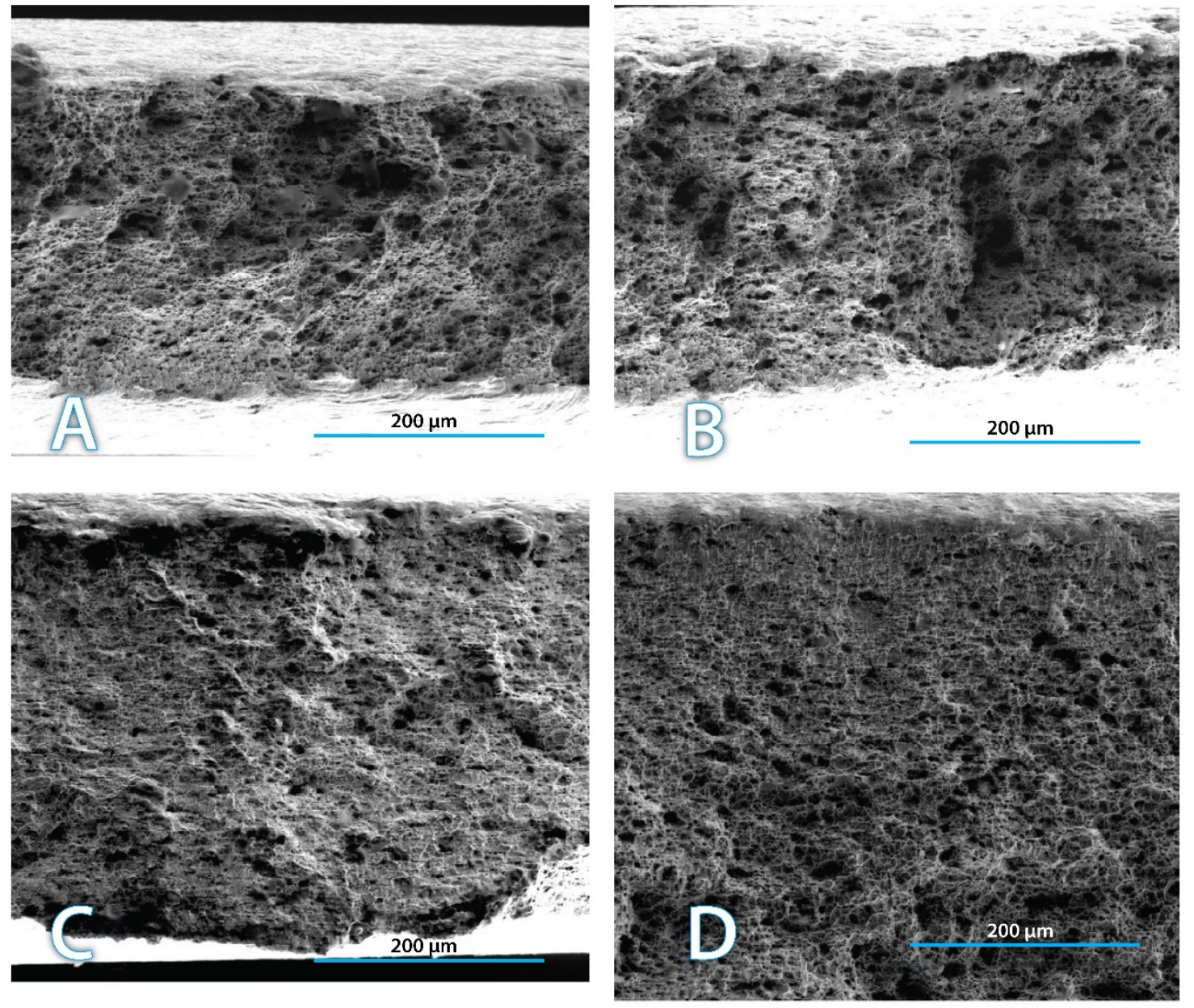

Fractography images set three, all foil conditions tested at elevated temperature $\left(200^{\circ} \mathrm{C}\right)$.

A) 551-2-2-L20-200 (50\%CW), B) 551-3-L4-200 (50\%CW+A), C) 551-4-L5-200 (20\%CW), D) 551-5-L4-200 (HR only). 


\section{Comparison}

- This work:

- RT yield stress: $\sim 1100 \mathrm{MPa}$

- RT ultimate stress: $\sim 1175 \mathrm{MPa}$

- RT elongation: 1-2\%

- Carbon: 710 ppm (1.86\% Vf)

- Grain sizes: $\sim 2-25 \mu \mathrm{m}$

- Hot rolled and cold rolled

- Waldron:

- RT ultimate stress: $\sim 617 \mathrm{MPa}$

- RT elongation: $0.1 \%$

- Carbon: $\sim 700$ ppm

- As-cast

- Grain sizes: not reported

- Ozaltun:

- RT ultimate stress: $\sim 790 \mathrm{MPa}$

- Carbon: 54-410 ppm

- As-cast and machined

- Hot rolled

- Grain sizes: not reported

- Causes:

- Thermomechanical processing history

- Grain sizes

- Impurity content

- NOT ENOUGH INFORMATION AVAILABLE TO CONCLUSIVELY COMPARE RESULTS 


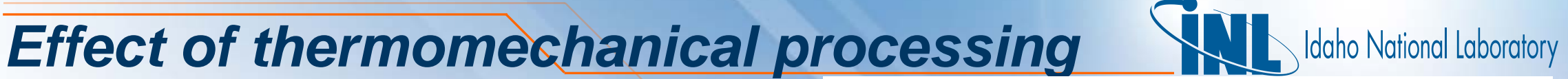

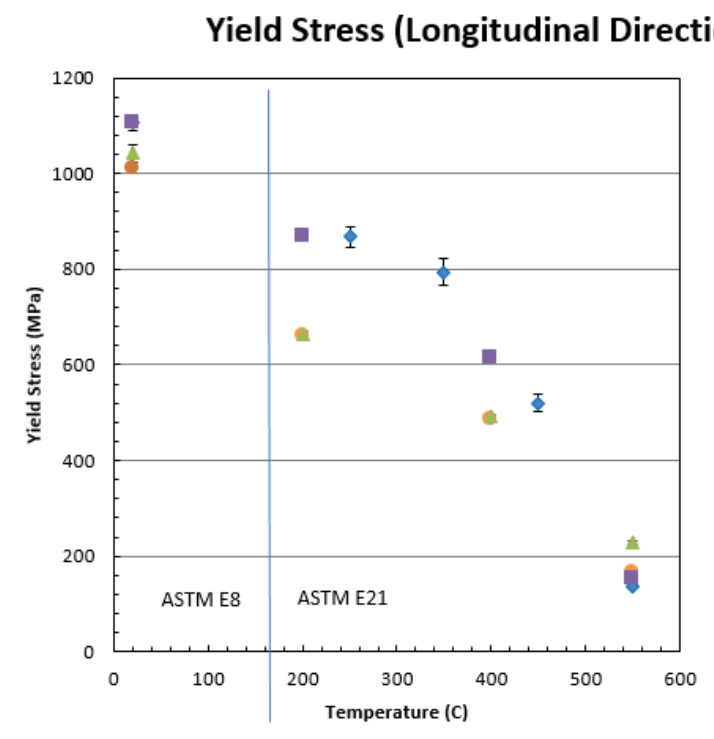

\$51-2-2 L Avg YS (50\%) - 551-3 L Avg YS (50\% + A) - 551-4 L Avg YS (20\%) $\triangle 551-5$ L Avg YS (HR)

Ultimate Tensile Stress (Longitudinal Direction)
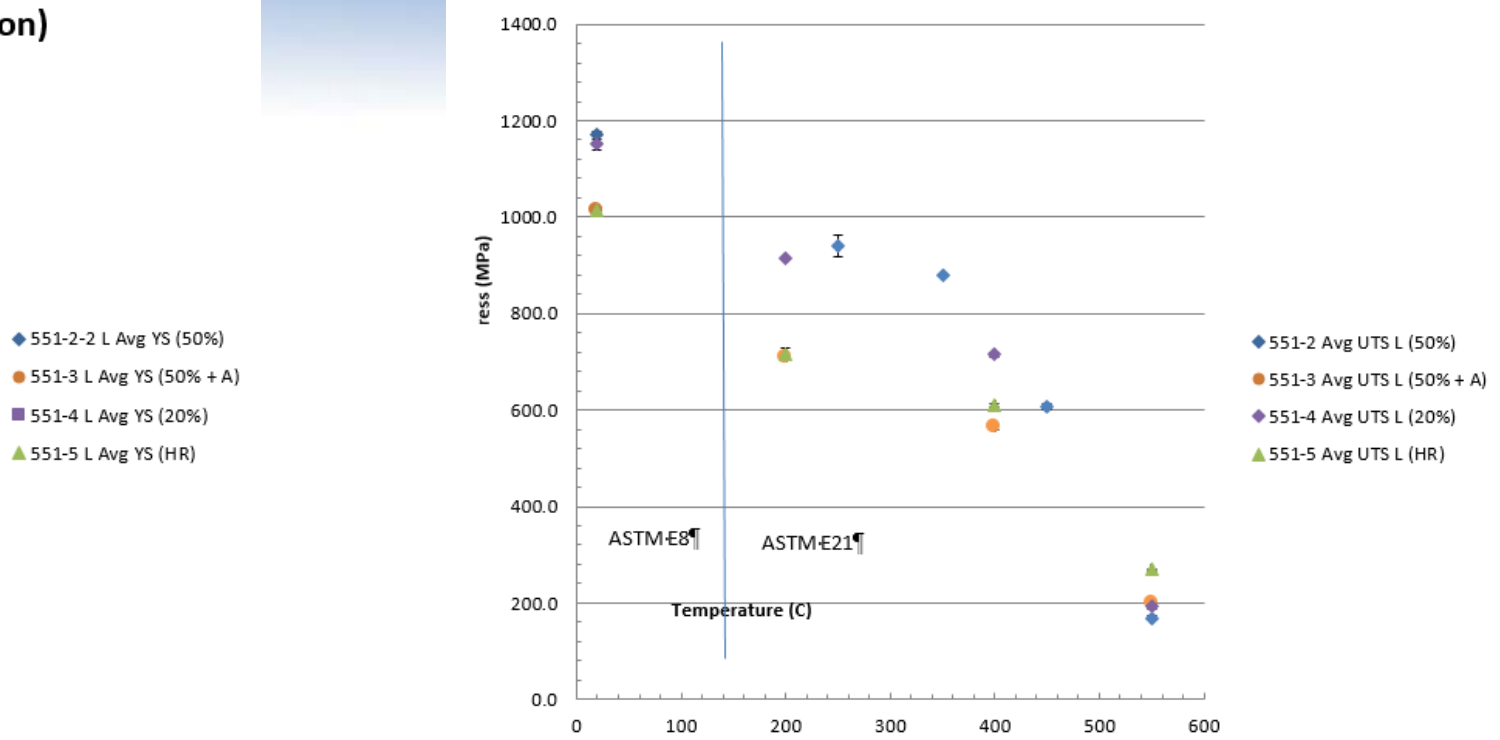

Yield Stress (Transverse Direction)

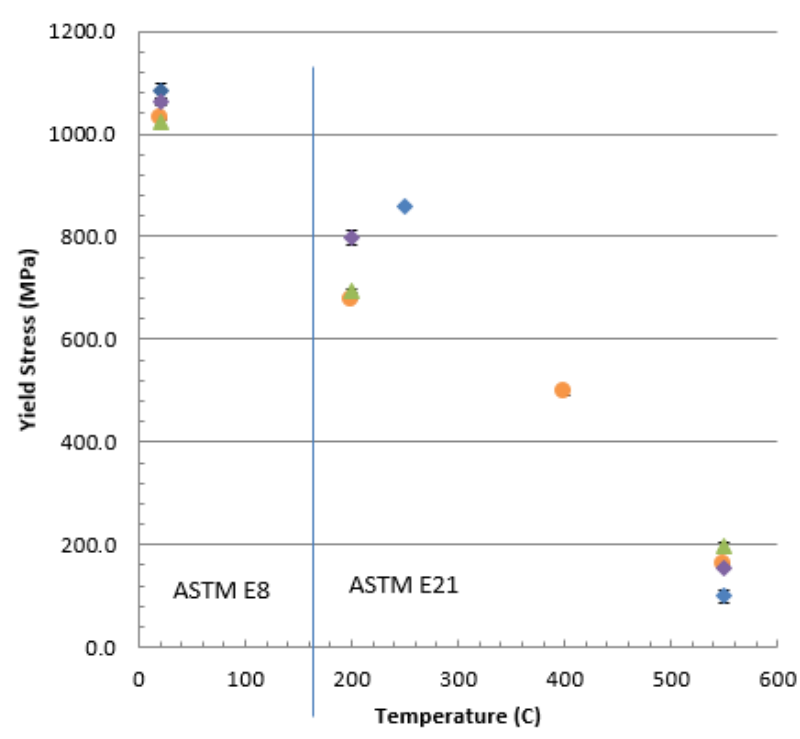

-551-2 Avg YS T (50\%) - 551-3 Avg YS T $(50 \%+A)$ -551-4 Avg YS T (20\%) $\triangle 551-5$ Avg YS T (HR)

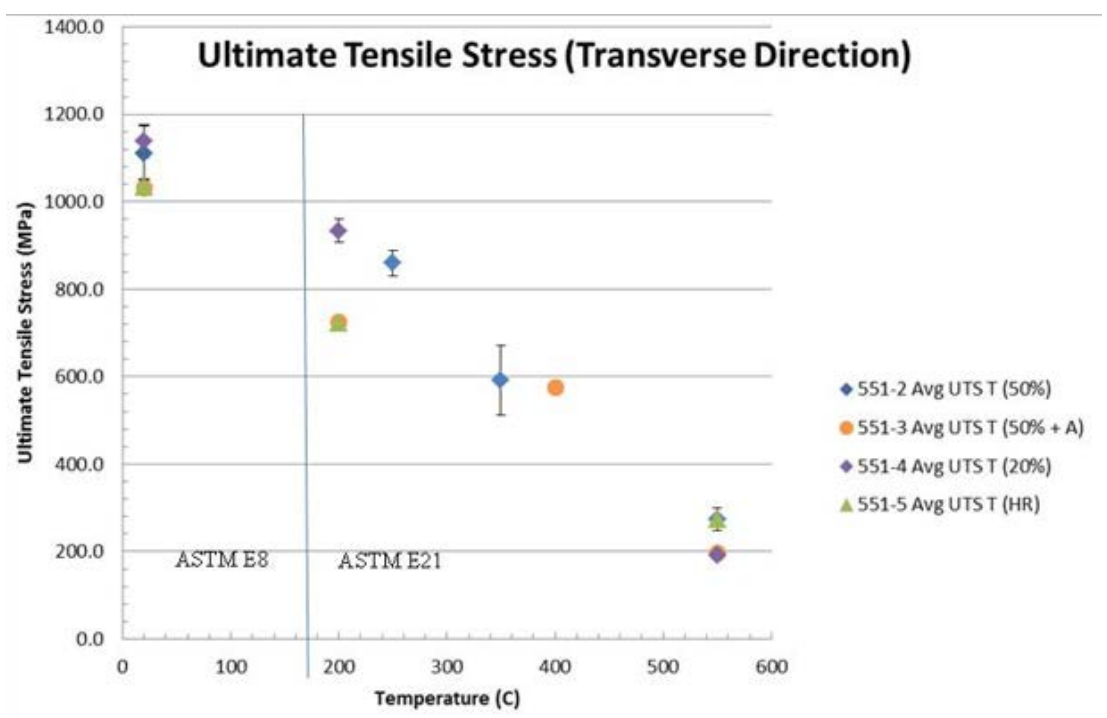




\section{PART 2 - Irradiated Properties}




\section{Existing Data vs. This Work}

- Gates (1958)

- Hot rolled, cold swaged, machined

- Extruded, cold swaged, machined

- Irradiation Temp: $130-600{ }^{\circ} \mathrm{C}$

- Burnup: 0.06 to 2.1 at.\%

- Test temp: RT - $500{ }^{\circ} \mathrm{C}$

- Beghi (1968) / Leeser (1958)

- Cast

- Irradiation Temp: $\sim 130-600{ }^{\circ} \mathrm{C}$

- Burnup: 0 - 2.1 at.\%

- Test temp: RT - $500{ }^{\circ} \mathrm{C}$
- This Work:

- Hot rolled, cold rolled (50\% reduction), annealed, HIP

- Fission density: $0.4 \times 10^{21}-6.3$ $\mathrm{x} 10^{21} \mathrm{f} / \mathrm{cm}^{3}$

- Burnup: $11.10-26.76 \% \mathrm{U}_{235}$ Depletion

- Irradiation Temp: $\sim 70 \sim 230{ }^{\circ} \mathrm{C}$

- Test temp: RT

- Previous work concluded that irradiation temp and burnup were most significant factors in mechanical properties degradation

- Differences in thermomechanial processing history, irradiation temp, and burnup make any comparison very difficult.

- Only 2 relevant data points from prior work:

- Burnup 0.4 at\%, Irradiation temp $130^{\circ} \mathrm{C}$, Test temp: RT; E $84 \mathrm{GPa}$,

- Burnup 1.0 at\%, Irradiation temp $200^{\circ} \mathrm{C}$, Test temp: RT; E $69 \mathrm{GPa}$ 


\section{Source Material, Specimen and Test Prep}

- Material from flat plate type fuel from RERTR-12 and AFIP-6 Mk2 Irradiation experiments

- Limited specimen machining capability drove decision to perform 4-point bend tests with rectangular specimens sectioned from plate fuel

- Customized Instron 5869 loadframe with custom 4-point bend fixture used for tests (2:1 support to load span ratio)

- Aluminum clad chemically dissolved from specimen leaving $\mathrm{U}$-Mo core coated with $\mathrm{Zr}$
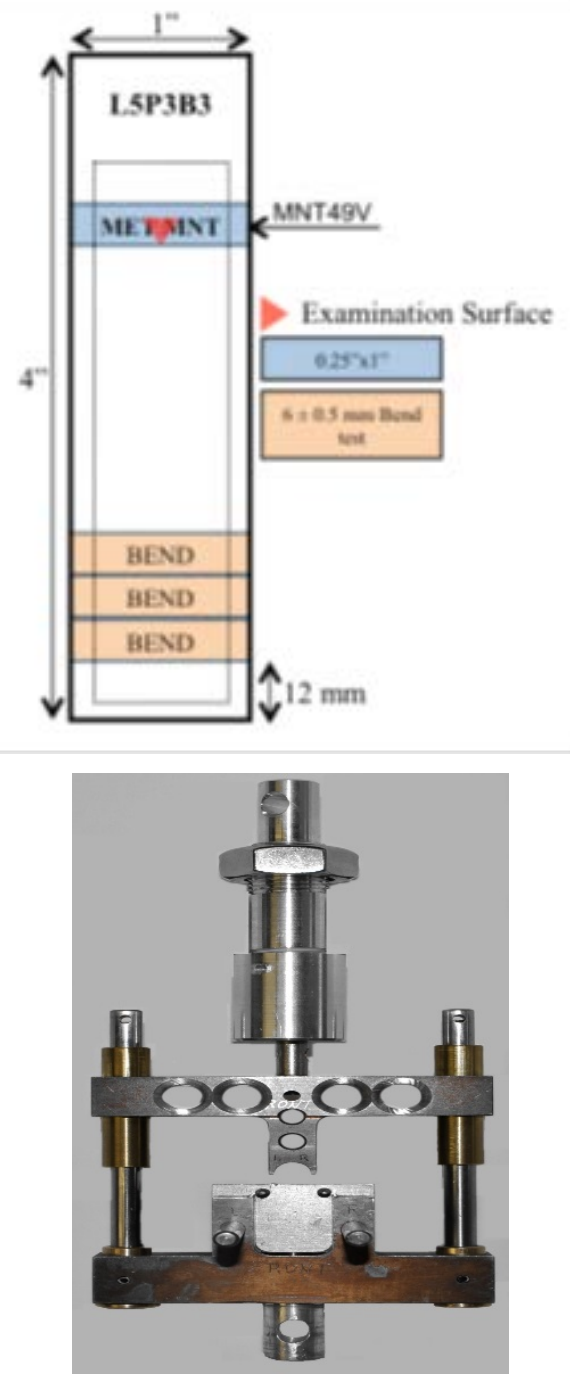


\section{Effect of irradiation}

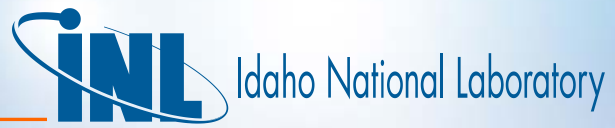

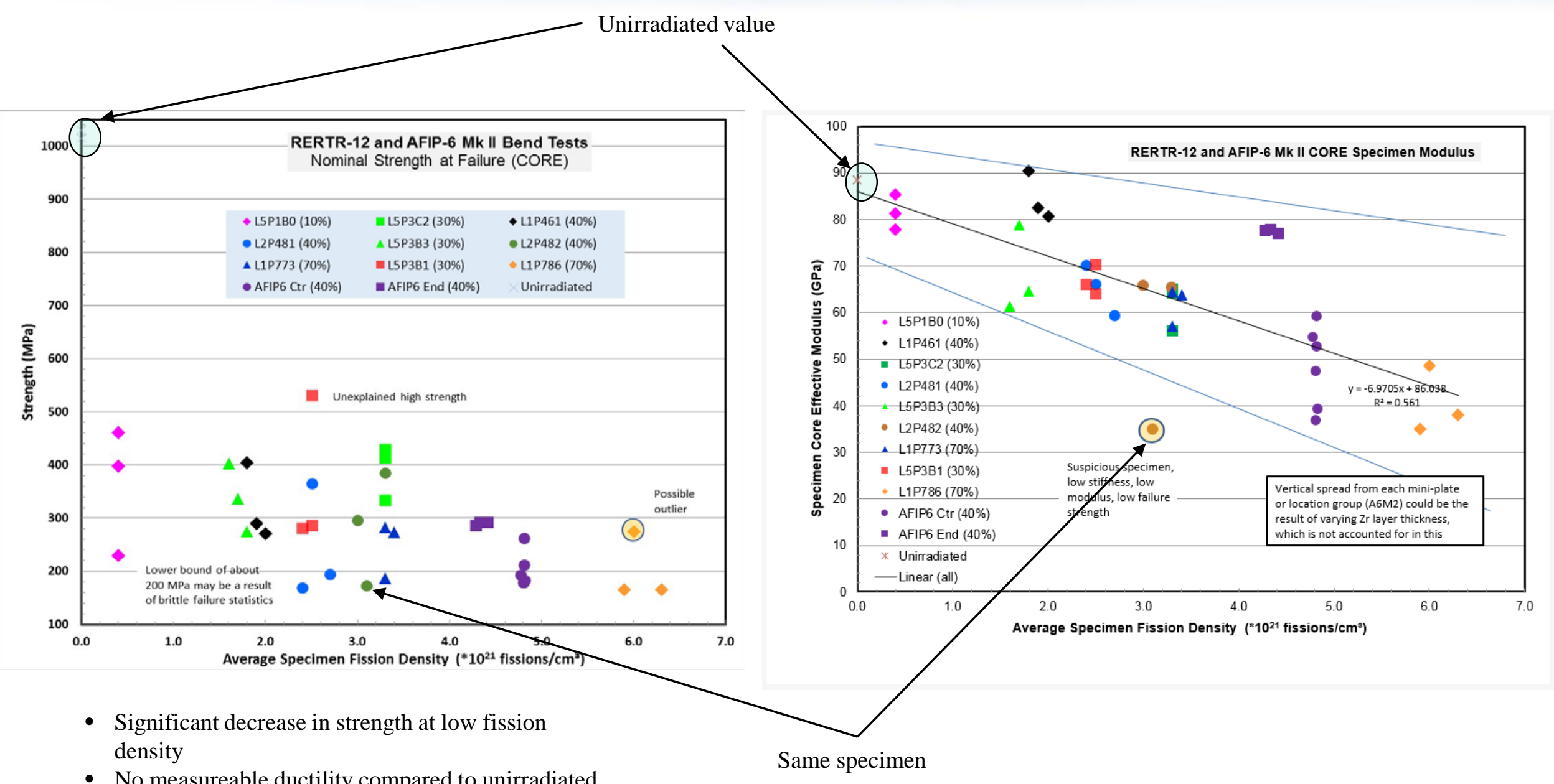

- No measureable ductility compared to unirradiated which had 1-2\% elongation (brittle failure) 


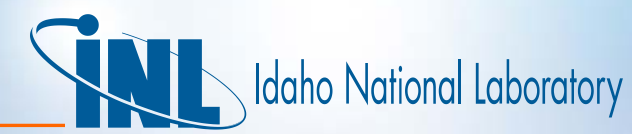

\section{What about porosity?}

- Previous work concluded that mechanical properties degradation was due primarily to irradiation temp and burnup.

- We also know that porosity increases with burnup/fission density and is also related to irradiation temp

- Can the mechanical properties degradation be related to the porosity?

Table 7. Summary of average phase fraction in percent for each sample.

\begin{tabular}{|l|c|c|c|c|c|}
\hline \multicolumn{1}{|c|}{ Sample ID } & $\begin{array}{c}\text { Fission } \\
\text { Density }\end{array}$ & $\begin{array}{c}\text { Carbide } \\
\text { precipitates } \\
{[\%]}\end{array}$ & \multicolumn{2}{|c|}{$\begin{array}{c}\text { Un-recrystallized regions } \\
{[\%]}\end{array}$} & $\begin{array}{c}\text { Porosity } \\
{[\%]}\end{array}$ \\
\hline & & & & $\begin{array}{c}\text { Region growing } \\
\text { sub-routine } \\
\text { excluded }\end{array}$ & \\
\hline AFIP-6 MkII Top & $4.53 \mathrm{E}+21$ & 1.0 & 22.3 & 13.8 & 11.8 \\
\hline AFIP-6 MkII Middle & $4.85 \mathrm{E}+21$ & 0.9 & 11.4 & 6.9 & 16.5 \\
\hline AFIP-6 MkII Bottom & $4.90 \mathrm{E}+21$ & 0.8 & 2.8 & 1.6 & 27.2 \\
\hline L1P755 & $4.67 \mathrm{E}+21$ & 0.0 & 10.6 & 4.7 & 13.3 \\
\hline L1P773 & $3.35 \mathrm{E}+21$ & 0.0 & 25.1 & 15.2 & 13.7 \\
\hline
\end{tabular}

Note: the samples in this analysis were taken adjacent to the samples used in the bend testing. Therefore, differences in the irradiation temperature and burnup/fission density between these samples and the bend test samples is considered negligible.

Table from Robinson et al (INL/LTD-18-50149) 


\section{What we know}

- $E=E(F D)$ (from experimental data)

- $p=p(F D)$ (from experimental data)

- Prior work from powder metallurgy field suggesting the following models:

$-E=E_{0}\left(1-b p^{2 / 3}\right) \quad$ Hyun (2001) (2/3 model)

$-E=E_{0}(1-b p) \quad$ Fryxell (1964) (linear model)

$-E=E_{0} e^{-b p} \quad$ Rice (1993) (exponential model)

$-E=E_{0} \frac{(1-p)^{2}}{\left(1+p b_{\theta}\right)} \quad$ Ramakrishnan and Arunachalam (1990) (non-linear model) 


\section{Compare experimental modulus with modulus predicted by porosity models}

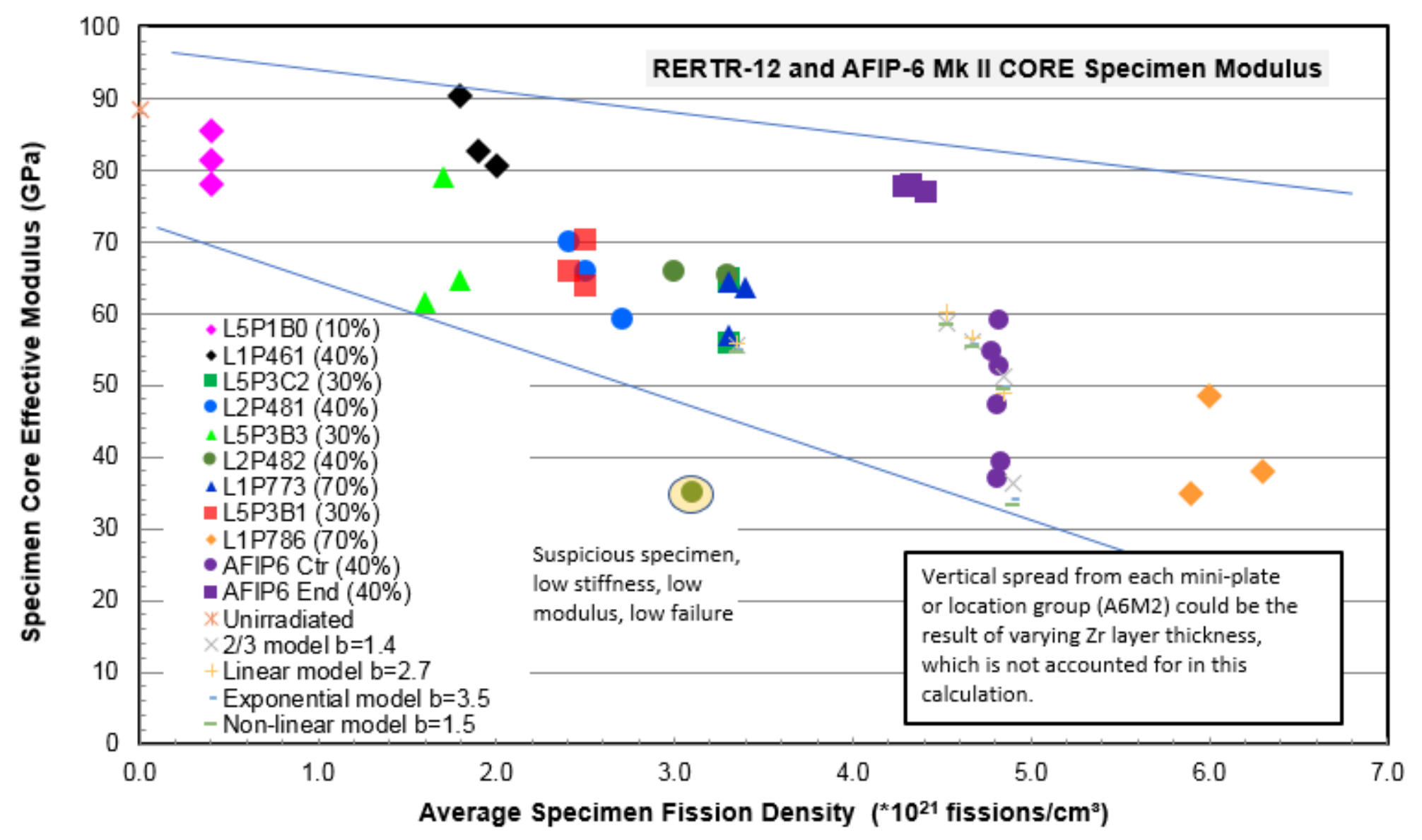




\section{Is there a best fit?}

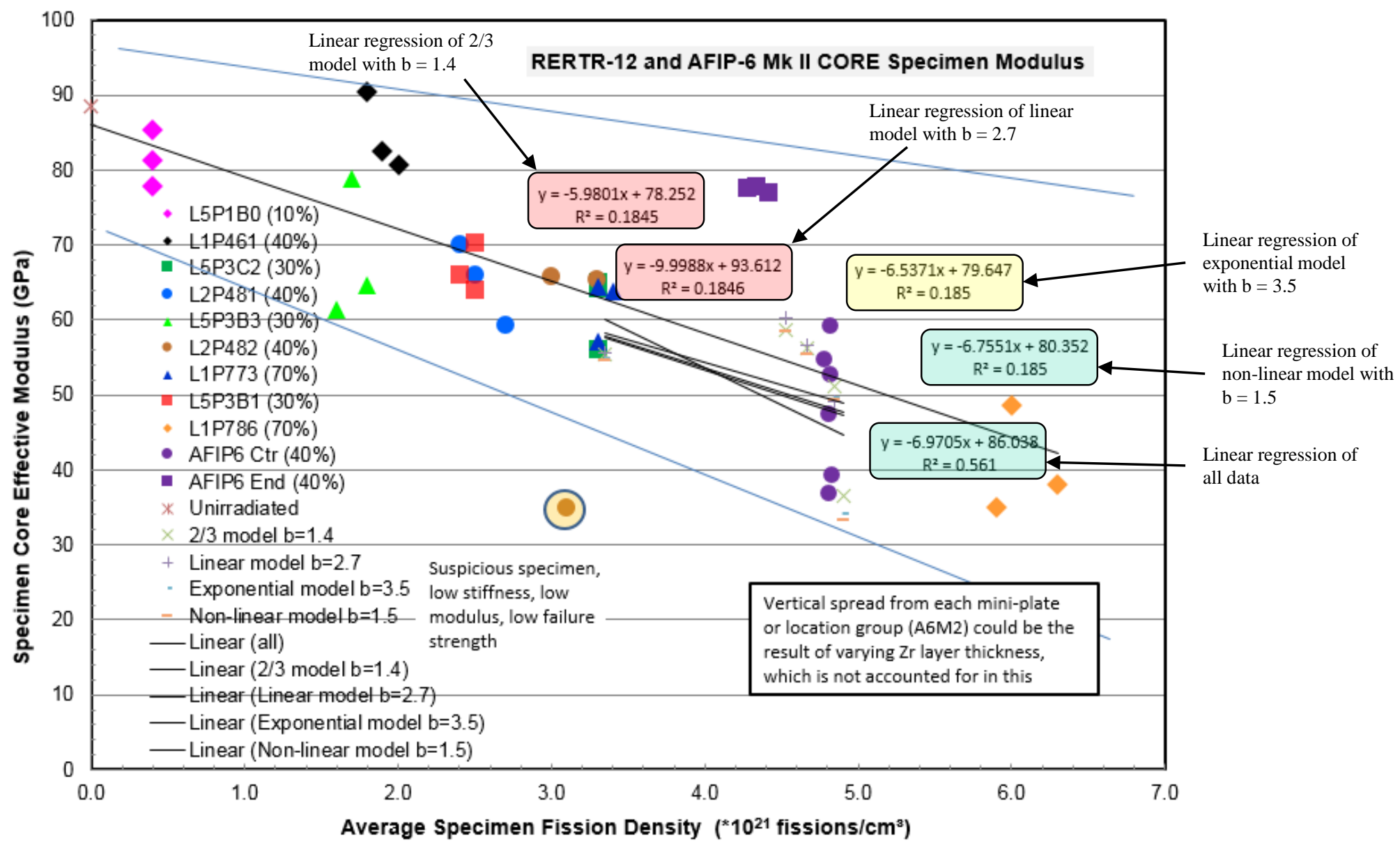


- PART 1 Un-irradiated Properties of U-10Mo -

- 4 fabrication variants tested from room temp to $550^{\circ} \mathrm{C}$

- Variants produced different yield and ultimate strengths at intermediate temps

- Higher strengths that previously reported, but comparison is difficult due to differences in material history, and missing information on historical material

- PART 2 Irradiated Properties of U-10Mo -

- Flat plate source material required use of bend testing through custom load frame and 4-point bend fixture

- Limited previous data exists, comparison is difficult

- Significant reduction in strength with low fission density, decreasing trend in modulus observed

- Large scatter in data, small number of samples available, brittle failure mechanisms based on no ductility observed

- Limited porosity data available

- Compared predicted modulus from porosity model to experimental modulus, reasonable agreement given limitations in available data

- Recommendations -

- More work is needed to understand outliers (microscopy), and improve statistics (more samples)

- Fracture modeling to evaluate sensitivity to pore size and volume fraction may be helpful 


\section{Acknowledgements}

- Randy Lloyd

- Barry Rabin

- Katelyn Wheeler

- Thomas Walters

- Michael Heighes 


\section{Idaho National Laboratory}

\section{QUESTIONS?}

